\title{
Citizenship and Religious Identity in Senegal (1970s-2000s)
}

\author{
Ndiouga Benga \\ University Cheikh Anta Diop, Dakar, Senegal
}

\begin{abstract}
Senegal is characterized by a democratic State and a will of Vivre ensemble. This specificity is challenged by new identities, including Islamic ones and spread through the public space after the Iranian Revolution in 1979. Some of them organize to win state power, having concluded that the existing political context is the main obstacle to social reform. They regard citizenship as practice. The returning to an Islamic Ummah was kept aside. Who should govern? How to govern? To face political Islam, the Senegalese ruling class has always encouraged the forms of religious mobilization considered to be non-oppositional. Beyond this political debate, the tradition of dialogue de vie, based on mutual acceptance, mutual respect for freedom of conscience and worship, sharing and cooperation, takes place in all fields of common existence between Muslims and Christians in Senegal. The rediscovery of Islam as the lieu of widening of the public space, renewing with the tradition, understood as a movement, an openness and a pluralism, without erasing the identity of non-Muslim minorities in their right to be different, symbolizes somewhere the capacity of innovating of the Senegalese citizenship in a secular State.
\end{abstract}

Keywords: citizenship, dialogue, Islamic discourse, pluralism, recognition

\section{Introduction}

The issues of citizenship and identity have been a major theme in political debates. These two phenomena, which are a priori distinct, raise the question of the relevance of the concept of nation-state and its constitutive elements, as well as that of the relationship between nation-states and citizenship on the one hand and identity on the other. The question of citizenship is particularly important as it is intertwined with the issue of recognition. The demand for recognition allows groups that claim a specific identity to emerge from the political sidelines and to be fully integrated into the state's structures. In this regard, being recognized is linked to a struggle for emancipation. Although citizenship may find its expression in various areas (voluntary associations, cultural communities, civil society), only "legal" citizenship allows for a full participation of individuals and groups in a political community.

In the case of Senegal, where 94\% of the population are Muslims, and 6\% are Christians or others religious belongings, the assertion of an Islamic identity is construed as a challenge to the doctrine of a single nation characterized by its cultural unity and the common identity of its citizens (Benga, 2010, pp. 237-260). This principle of unity claims to mask all differences in the public sphere. Identity is an effect of prejudice (marginalization by the State) to be transcended and an affirmation too. Ignoring this identity poses the problem of equity between different identities and how they are represented (belonging and State). Another important issue one has to acknowledge is that globalization by making the boundaries of the State permeable compels

Ndiouga Benga, Ph.D., Senior Lecturer, Department of History, University Cheikh Anta Diop.

Correspondence concerning this article should be addressed to Department of History, University Cheikh Anta Diop, B. P. 5005 Dakar-Fann, Senegal. 
researchers to abandon the homogeneous and the unitary concept of citizenship in favour of a plural-concept one. The persistence of the Nation-State as a model political unit relies on its capacity to negotiate within and beyond national borders its capacity to negotiate its identities. In face of a secularist State and globalization that in actual fact boils down to westernization (according scholars like Fukuyama), homogenization and standardization (but distinct local, state, and regional contexts, shape and reshape the otherwise uniform patterns and processes of globalization in particular ways of hybridization or glocalization), the aim of radical Islam is to propose another way, another cultural process of subjectivation, another social contract, where Islam is a central force in politics and where God rules. The question one may ask is to know whether this sort of control doesn't lead to the emergence of a passive form of citizenship.

\section{Citizenship and Identity: A Conceptual Framework}

There are differences and affinities between the concepts of citizenship and identity that generate significant problems in addressing both. In terms of differences, citizenship is more of a concept of status than identity. It is expressed in juridical and legal norms that define the rights of the members of a polity. Many scholars argue for a concept of citizenship broader than a juridical and legal status, but these arguments do not change the basic fact that ultimately citizenship allows or disallows civil, political and social rights and obligations in polity. Such arguments for active citizenship or deep citizenship are concerned with deepening the scope of citizenship, but they nevertheless presuppose the status of citizenship that already exists. While identity does not need to have a legal and juridical basis, it may become the subject of legal dispute and struggle. Although identity formation is a process that begins outside the purview of legal rules and regulations, it is often drawn into the legal field. This is also its strength. "Identity" is a concept that presupposes a dialogical recognition of the other; it is a relational concept. But it is also a concept that presupposes identification in the sense that individuals recognize attributes or properties in each other that are construed as identical or at least similar. These properties, then, are used as an index of individual position and disposition. Identity is therefore a concept not so much of uniqueness or distinction as of resemblance and repetition (Jenkins, 1996, p. 34). By contrast, an individual is a distinct assemblage of identities. Thus, individuality should be kept distinct from identity. When we use the concept identity, we invoke a classification that places and positions an individual within a social place by virtue of his or her various identities.

The formation of group identify is a process whereby individuals recognize in each other certain attributes that establish resemblance and affinity. This becomes the basis of identification whereby individuals actively produce and reproduce equivalent dispositions. Although identity too can become a status concept, especially a social status, it should rather be thought as the basis of recognition demanded by groups excluded from the scope of citizenship. The affinity between citizenship and identity is that they are both group markers. Citizenship marks out the members of a polity from another as well as members of a polity from non-members. Identity marks out groups from each other as well as allowing for the constitution of groups as targets of assistance, hatred, animosity, sympathy or allegiance. As group markers the difference between citizenship and identity is that, while the former carries legal weight, the latter carries social and cultural weight.

In Senegal, the fixed and stable boundaries of identity have been challenged by new identities [including Islamic ones: Union Culturelle Musulmane (UCM, 1953), Al Falah (1975), Jamatu Ibadu Rahman (JIR, 1978), Association des Etudiants Musulmans de l'Université de Dakar (AEMUD, 1984), Organisation pour l'Action Islamique (OAI, 1986)] (Rosander \& Westerlund, 1997, p. 77; Villalon, 2004, p. 67) and their fluidity (but also 
their new rigidity) and raised questions about the nature of social groups (Young, 1990, p. 56). Moderate movements (Al Falah, JIR, AEMUD) organize and agitate for social reform within the existing political context. Radical movements (UCM, OAI) organize to win state power, having concluded that the existing political situation is the main obstacle to social reform. For the latter, Islam is not just a religious or cultural identity; it has become a political identity. Islamic reformism is not something new in Senegal. It appears regularly like a counterculture's movement which is an upholder of the purification of the practices which are perverted either by other cultures and religions or by deviations inside Islam, such as sufism. Contemporary reformism is not only defending a traditional Muslim identity opposite to the process of westernization. It aims to restore the purity and the universalism of Islam.

In fact, it tries to find again the authentic forms of this religion from the outset, the behaviors and the abilities it has brought about to the first Muslim followers. However, there is no deviation. Unlike to the reformist viewpoint, what really matters is how to reconcile Muslim tradition marked by the completion and the closure to the demands of reason, to the critical mind and the intelligibility, how to create the dialogue between the revealed Word and the reason invited to interpret it freely. La fidélité est dans le mouvement (Diagne, 2001; Brown, 1996, pp. 60-80; Berque, 1993), the meaning comes from the future, understood here as a reconstruction task, as a systematic refusal of a completed and fixed world.

Some have argued that the politics of identity has fragmented the political strength of class-based groups. How can a conception of politics recognize and respect group difference, and then allows for building alliances and blocs to struggle for rights? Citizenship, despite being a modern and universalistic rhetoric, has always been a group concept, and has never been expanded to all members of any polity. Even in a democratic State like Senegal, many members of polities are excluded from the scope of citizenship even if they are legally entitled to its benefits, in the meaning of the relationship between the equality of citizenship and the inequality of class (Marshall, 1992, p. 6). During the 1993 presidential elections, the JIR had developed an Islamic platform for candidates, requiring an explicit application of Islamic law in all areas of life. In exchange for the satisfaction of this condition, any candidate would benefit from the support of this Islamic organization. The result was inconclusive. In 2012 general elections, the Reform Movement for Social Development, a political party close to the Islamic movement has used the same strategy, within a broad political alliance. This time, the result was convincing as this party won two seats at the National Assembly.

While it is therefore a mistake to conflate citizenship and identity, it is also a mistake to see them as antagonistic concepts. There is certainly a tension between the universal aspirations of citizenship and the particularistic claims of identity. Nevertheless, since citizenship has never been universal, it is more appropriate to interpret the different forms of group identities as claims for recognition of citizenship rights. For Senegalese Islamic reformers, it is important to struggle for earning rights, to move from theoretical and normative views of citizenship politics and ongoing practices and to generate and explore an ensemble of different forms of belonging rather a universal or unitary conception. They regard citizenship as practice. They address the question of what happens to citizenship when we acknowledge the challenge of identity/difference politics. The inclusion of everyone requires special rights attending to group differences, the recognition of difference. What happens to different types of citizenship when we attempt to accommodate group difference and articulate a broader principle at the same time?

The dismantlement of traditional communities and their replacement by larger national entities has resulted in the ending of the traditional way of life and in the subsequent religiosity (Gellner, 1981, p. 178). 
Such a peculiar religiosity prospers in the rural areas, and among the poorest urban communities. It is based on the cult of Saints, and performed through myths, celebrations and rites, basically intended to ensure and maintain the social cohesion of the group and its integration in its natural and human environment.

Mention must be made here of the role of Muslim brotherhoods (Coulon, 1981, p. 70; Piga, 2002, pp. 193-284). They are closed to Senegal's history. They are at the origin of the theocratic States in Senegambia between the 17th and 19th centuries (Barry, 1998; Robinson \& Triaud, 1997; Diouf, 2001). They are a blend of complex social networks, religious movements, political parties and economic activities. They embody a popular Sufism which is strongly marked by the local context. In Senegal, Muslim brotherhoods are a modern phenomenon, because not only are they relatively recent but also they act as a relevant instrument to fit modernity. They played a major role in the single-crop production of peanut; they organized its market while negotiating with the colonial and postcolonial State. They have been able to manage the single-crop farming crisis in the 1970s and the migrants flux. They are financial and commercial networks for import-export goods between Senegalese migrants living abroad, mainly in Italy, Spain, France, Central Africa, the United States of America, China and Hong-Kong, etc. and those who are living in Senegal, where Muslim brotherhoods, known as daa'ira in the cities, intervene in many fields specially in job, housing, wedding, solidarity etc. in order to help their members. In the informal sector, many young people develop solidarity by helping their friends who are members of the same religious association to launch in business (Diop, 1980).

Therefore, a new type of religiosity has been initially nurtured in people's mind by urban elites who have access to the written heritage. Religion therefore is tantamount to a doctrine and a set of norms and rules that govern people's behaviours in the name of a revealed truth. The ideal of returning to an Islamic Umma (community) comes from this change: This would be the resurrection of a hope and representations that were provisionally kept aside by both the urban elites who were powerless in front of an effective colonial power, and the rural and urban masses that used to be locked in strong local representations and memberships. The people from the Islamic cultural space therefore have two identities: One which is a result of their membership in a State which provides a source of identity and belonging and another one defined by their faith (religion). What is happening nowadays is just like renouncing one identity for another one, as the national identity has failed to take root and gain legitimacy (Gellner, 1994, pp. 15-29). These two aspects are reconcilable. The essence of the State is the protection of individual rights, but recognizing this cultural community's rights may entail respecting the importance and centrality that this group attaches to its cultural heritage.

The most important development as a result of such a process is the emergence of the salafi, the militant who committed himself to restoring attitudes that are deeply rooted in the Islamic ethics of the "pious ancestors", a character who symbolises the aspirations and frustrations of a society that is confronted with various serious challenges. The Salafi is a mixture of qualities and attitudes that make him a "saviour" of the community: opposition and critics to the Muslim brotherhoods (the denial of the sacredness of the relationship between the master and the disciple) and witchcraft systems, alliance with nationalism and denunciation of European imperialism, commitment to both faith and tradition, self re-assertion. Everything tends to make him apt to help society recover its balance and self-confidence. In Senegal, Islamic reformism, which emerged in the 1930s, spread through the public space after the Iranian Revolution in 1979 and mainly with the expansion of a puritan Islam in the Arab sunnit countries. In Africa and specially in Senegal, this reformism sponsored a network of teaching schools and institutes led by a young elite committed into a triple movement of 
individuation (Leimdorfer, 2003), of challenging the hierarchy and of eastern globalization (Appadurai, A., 1996).

\section{Allah or the Republic? Islamism and Citizenship for Another Social Contract in Senegal}

The Senegalese social contract refers to the exchange of favours between the postcolonial State and the religious leaders power (O’Brien, 1992, pp. 9-20; Diouf \& Diop, 1992, pp. 65-87; O’Brien, Diop \& Diouf, 2002). The State is no longer the only source of modernity. Muslim brotherhoods and reformism are trying to widen their action of promoting an Islamic society in Senegal within a tactical compromise (Diop \& Diouf, 1990; Seck, 2007).

The first doctrinal expressions of the modern Islamic reformers set up on a certain distance to the democratic principle proclaimed by the State and a number of them continue to make of the "primacy of the divine will over that of the people", a reading which seems well to compromise the chances of short-term progression of the building of citizenship. Today, the Islamic reformers' attitudes vis-à-vis the concept of citizenship cover in fact a spectrum which goes from acceptance without conditions or reserves to a more automatic and utter rejection of this notion. The idea that the "citizenship formula" jeopardises the primacy of religious norms remains central in the argumentation of several of them. For them, it is out of the question to give up the principle of divine guidance, and to yield blindly to western experience of citizenship models. Do these more or less radical criticisms levelled against western democracy confirm the assumption of a total incompatibility between the dynamics of resurgence of Muslim culture categories and the respect and the development of human values? The functions of Islamic political discourse are not limited to the logic of "identity resourcing" and to individual or collective patterns of life. This ideology of identity resourcing functions much rather as a protest language. The critical reading of the western legacy thus makes it possible to express its distrust to the regime and the identity dynamics often viewed as a dynamics of opposition (Otayek, 1993, p. 27). The principle of glorification of a divine authority is enough to make banal the holder of an only secular legitimacy. The evocation of the absolute character of the divine monarch makes it possible to underline the contingency of its human competitor. To face political Islam, the Senegalese secular ruling class has always encouraged the forms of religious mobilization considered to be non-oppositional (Loimeier, 2000, pp. 185-187; Piga, 2002, pp. 214-215).

On the contrary, Islamic discourse, virgin of any compromising with the State, can effectively exploit utopian dimensions inherent to the opposition discourse. The Allahou Akbar (God Is the Greatest) which comes from mosque meetings expresses the rejection of the West but also of the secular and corrupt elites; in other words, according to Islamic logic, such words express hostility to the normative and endogenous symbolic system.

The increasing incapacity of the regime to collect the benefits of the ré-islamisation can be viewed as an ultimate contradiction: the credibility of Islamic political discourse is incompatible with the allegiances that the economic difficulties and the French and American pressures force the State to adopt. Normalization of the diplomatic ties with Israel also irresistibly tends to transfer access to nationalist profits to those opposed to it, i.e., essentially, Islamic reformers (Diop, 1992, pp. 265-266; Mamdani, 2005, pp. 17-20, 36-38, 45-62).

The State wanted to take the place of religion, in other words, to take control of the soul, mind and feelings of the people, rather than to deal with their bodies, their reasoning and interests. It wanted to exercise hegemony over belongings, and to be obeyed. As a result, instead of being the promoter of national policies and 
the source of freedom values, it has become the means for collective alienation and the symbol of both repression and the outsider. As a result of such an evolution, there appeared what analysts call the failure or banning of the national State (Rodinson, 1993). This radical and narrow view on the nature of the Senegalese State refers to two questions: Who should govern? How to govern? Open questions addressed by the first Muslim community concerning the choice of the four successive caliphs according to different procedures. These questions certainly suggest the freedom to invent States, however, going beyond any identity or dogmatic tension and the rejection of the other as the bearer of evil. This is to reflect on the conditions of a modernity facing the need to revive the spirit of the reform (understood here as an internal movement) and a permanent openness, as well as the values expressed by this spirit: the assertion of the individual judgment, the idea of progress, freedom, the prize awarded to the scientific spirit. According to the Islamic reformers, the response of the upholders of the Islamic matrix has won or must win the battle against the abiding modern State model. This has resulted in a new paradigm. The idea of the Kalifat was replaced by the notion of "Islamic State” that won popular membership and involved several elites (Coulon, 1983, pp. 45-84, 156-160). Its strength probably comes from its critical attitude towards the State, as the latter provides the context and means for such an alternative to prosper. The "social contract" was broken. What explains the new tendency to oppose, in an absolute way, the religious and temporal systems is the disruption of the social creed (Hodgson, 1993, pp. 230-233). When the social creed weakens or breaks down, the society loses the shared vision of things, and has a different meaning for the concepts used both in politics, religion and society. It therefore becomes impossible to find a common ground.

It exists in Senegal a tradition of conviviality between Muslim and Christian communities. This tradition (dialogue de vie) means mutual acceptance, mutual respect for freedom of conscience and worship, sharing and cooperation. It takes place in all fields of common existence between Muslims and Christians who can be of the same ethny, of the same social milieu, of the same family. Religious feasts, Christmas and Easter, Tabaski (Aïd Al Kabir) and Korité (Aïd Al Fitr) provide an opportunity for reciprocal invitations. In the countryside as well as in the city, they live, work, suffer from the same difficulties of life, participate together in the political action, attend the same family ceremonies, pay visit to each other, appreciate each other. In Senegal, it is not uncommon for a family to have both Christian and Muslim members. This dialogue of life is shown at the beginning of the postcolonial period. On August 25, 1960, Senegal is independent, with Leopold Sedar Senghor, a Catholic, as president of the Republic (until 1980) and Mamadou Dia, a Muslim, as president of the Council of Government. The first plan of development of Senegal was initiated by Mamadou Dia who was inspired by Economie et Humanisme, founded by Louis-Joseph Lebret, a dominican father. This latter was chosen by Dia as the advisor of the Senegalese government for development. In February 1961, a joint Christian-Muslim declaration about the women dowry in Senegal, is written by the holy spirit father Henri Gravrand and El Hadj Falilou Mbacké, the murid brotherhood's leader. It recommended an amount of money not to be exceeded. On June 7, 1963, Leopold Sedar Senghor, while inaugurating the Mosque of Touba, the holy city of murids, invited Muslims and Christians to pray together. This dialogue is a recognition of the contribution of each one to the common good and a powerful factor of unity (Diouf, 2001).

The issue of State and Religion actually corresponds to a twofold crisis: one as a result of the need to re-define norms for the civil society, and the other one imposed by the re-shuffle in the religious conscience. The religious representations are therefore soon adopted by the marginalised crowds, as they are confronted with a strong feeling of a block and lack of material and moral future (Gellner, 1992). 
The alternative passes, in the hard core of Islamic discourse, by the restoration of "divine sovereignty" and the rehabilitation of the normative order. And the Islamic State is thus a State where rulers respect a basic requirement: controlling mankind "with what God revealed", i.e., the divine law, the Shari'a of God. The political program of all Islamic formations thus grants without surprise a central place to this claim (of Shari'a) or that of the restoration of Dawla Islamiyya or Islamic State. In the version of Islamic political discourse, the restoration of "divine sovereignty" and the enforcement of Shari'a which results from this must be enough to satisfy the totality of the normative needs of society. In Sudan, Mauritania, Nigeria, Egypt, and Morocco, the freedom of worship is being challenged. Discrimination based on religion is the rule, to various degrees. The renunciation of Islam is punishable by death penalty in Mauritania and Sudan, by prison in Morocco, by the loss of the right to inherit and keep one's children in Egypt. Christian conversion is punishable by the death penalty in Sudan, and is forbidden in Mauritania, Somalia, and Tunisia and is highly unadvisable in Niger.

However, if the principles achieve unanimity, the interpretation of the concept of Shari'a and the concrete conditions of its implementation leave room to substantial divergences. Even if it is represented like celestial essence, the "law of God" is nonetheless the result of a perfect human mediation: Except a limited number of explicit commands, the law of God imperatively requires the interpretation of lawyers (fuqaha), who can be "in communication" with the environment which requests their knowledge.

The concept of "Islamic State" is sustained, not with really innovating theoretical developments, but by the failure of the post-independence national State (Vuarin, 1990, pp. 601-634). It paradoxically establishes the omnipotence of the State institution that it seeks to oppose. It actually leads to "fetishizing" the State, the form or the structure of which it is trying to take. The failure of the national ideal, then of the reforming ideal —which are unable to create the conditions for the construction of a stable political society, and to achieve the principle of citizenship as a mark of political civilization in the present times-did not only contribute to exacerbating the crisis in the new and older political systems. It also revealed the crisis in the relations with the social authority and the social system's need for the earlier founding principles. Radical Islam, as the extremist form of such criticism, obviously seeks, through the following three postulates-backward-looking, commitment to rites, commitment to social change-to re-establish the link between religion and politics, to subject the State to the symbols of the paradigm of the eternal and unchanging truth (Magassouba, 1985; Gomez-Perez, 1994, pp. 79-98).

The consensual requirement of Shari'a implementation, i.e. restoration of the Muslim normative order which is in the heart of the Islamic pressure is the subject of countless appropriations and expressions. In Senegal, the exhaustiveness and steadiness of Shari'a are just a myth rather than a reality. Obviously difficult situations appeared in this religious coexistence in Senegal.

In Joal, on October 19, 1884, the members of the Holy Rosary and many Christians sent to the bishop and to the governor of the colony a letter to oppose to Muslim clerics attempts to settle in the city. In the same way, the missionaries of Sine and Baol got from the governor of the colony Chaudié, on July 12, 1899 that the appointed Muslim leaders who were guilty of injustice towards the population to be dismissed (de Benoist, 2008). The Catholic church in Tivaoune, built in 1895, in the religious capital of tidianyya in Senegal, which fell in ruin, was replaced by a new one in 1986. The announcement of its opening was subject to a fierce opposition from Muslims. The Cardinal Thiandoum decided to meet the leader of the tidian brotherhood. The Episcopal Conference of Senegal took the decision to cancel the opening and to follow the decision of the State to compensate the Church and to make of the building a public use. Between 2000 and 2012, the President 
Abdoulaye Wade, who was a fervent murid submitted himself to the authority of the caliph of this brotherhood. This had caused the perplexity and even the disapproval of Senegalese people which considered it as the Republic kneeling before the Muslim leader (Sèye, 2007, pp. 165-182). Differences of opinion have also been noted in the understanding and in the implementation of the Family Code.

But in terms of religious peace and national cohesion, nothing is ever granted. There is a strong concern about permanent dialogue, within the respect of cultural and religious differences. Father David Boilat emphasizes it in his Esquisses Sénégalaises: "Wherever he goes, the marabout (Muslim cleric) is welcome; people are honored to house and feed him, his presence alone should sanctify his guests [...]. The prestige of the marabout is so rooted in the heart of the people of Senegal, that it splashes up the priests of other religions. One only needs to be men of God. The catholic missionary is received everywhere with the same kindness and even love” (Boilat, 1984, pp. 481-482).

The colonial period witnessed civility in urban areas, such as St. Louis and Gorée where Muslims named their children after their Christian friends (Diouf, 1997, pp. 837-850). In some parts of Senegal (Ziguinchor, Fadiouth, Palmarin), Muslims and Catholics are buried "together". They share the same cemetery. Melting pot of dialogue and learning about living together within respect and tolerance, catholic private school has been present in Senegal since 1818. It welcomes pupils of all religions, a large majority of which are Muslims. It has participated in the training of many leaders in the nation. The late Archbishop Hyacinthe Thiandoum (1921-2004) and the Pope John Paul II's visit in Senegal made a greater sense to this common ideal of a shared citizenship in Senegal. Thiandoum, who came from a mixed catholic and Muslim family, was ordained priest (1949), bishop (1962), and cardinal (1976). As the head of the Catholic Church of Senegal (1962-2000), he worked, as a blacksmith, for the Christian-Muslim dialogue in his country and abroad. Thiandoum sustained a special relationship with the Muslim brotherhoods leaders (tidian, murid, layen) and the lebu dignitaries who had welcomed the catholic missionaries in Dakar in 1845. Mamadou Dia wrote at the death of Thiandoum: "Cardinal was my brother and my friend of good and bad days (...). We both practiced the Christian-Muslim dialogue, before it has been institutionalized”. Dia also described Dominican father Lebret as a contemporary heroism's witness. Pope John Paul II visited Senegal on February 19-22, 1992, at his 8th trip in Africa after the organization in Dakar of the Islamic Conference's meeting. He was invited by the Muslim president of the moment, Abdou Diouf (1980-2000), whose wife was a Catholic. The Pope had already visited predominantly Muslim countries such as Turkey, Morocco or Indonesia during his pontificate. While in Senegal, he met Muslim leaders representing all the brotherhoods (Sèye, 2007, pp. 165-182; de Benoist, 2008).

The issue of Islamic law governing contemporary societies is reduced to its real dimensions: The tradition by which people want societies to remain static has nothing of that concrete block its champions believe in, or even want people to believe in. It has always confessed its relativity, and has even developed based on the belief that it is an approach "located" in time and space, with the aim to implement higher principles. It comes out as a collection of precedents (the Islamic Law or figh), rather than as a systematic application of a single/standard norm.

One will be able to see in the Shari'a the minimal direction given by the Quranic text of a "way" or of a state mind. The enforcement of Shari'a then means only the need for the Muslim legislator to impregnate the revelation spirit, to keep present the existence of this corpus of high principles putting an end to the autonomy of human will without denying human beings territories of expression (Otayek, (Ed.), 1999, p. 11). 
In Senegal, it seems that the more the reading of the legal corpus of Shari'a will be literalist, the tinier the autonomous space of citizenship and its possibility of playing an essential role of regulation will be. But what is also true is that tensions between reformists and Sufis in the spaces of public deliberation don't mean conflict between modernity and tradition. They refer to two rival and interlinked forms of modernization, two ways of ré-islamisation (Roy, 1992; Kepel, 2003), in their quest of a new Senegalese modernity. This ré-islamisation does not necessarily lead to an Islamic State, but it gives substance to the nation-state, to an everyday life Islam. It seeks to become in the public sphere the common language of the nation, without erasing the identity of non-Muslim minorities and the secular and democratic tradition of Senegal. Basing itself on the Constitution and the coexistence within the tolerance, the Church of Senegal claims a full citizenship and the assertion of its own personality or the right to be different in a society lieu of integration for all (Ndiaye, 2002, pp. 601-616).

\section{Conclusion}

To a culture perceived as an "imported" one from western overseas, it is likely to be easily substituted here by another one. It is very logically this form of relation to the "divine norm" and the historical inheritance which justifies the most obvious criticisms against the Islamists, in particular that which denounces their incapacity to historicise the relation with their heritage. Nevertheless, the "Islamic" norms, which are divine ones, remain perceived as endogenous compared to a positive law of western inspiration and in that satisfy the needs for "authenticity". Some contemporary movements build on the doctrinal and normative aspect of the Islamic creed to offer what they consider to be an alternative to the model of reference (the "western model"). It is true that such movements enjoy popular support whenever there are opportunities for democratic changes (Lewis, 1998). Isn't it more likely that such a resort to the Islamic norms is the result of a society's response in front of a democratic State that has been moving out of control? Isn't it better to assume that we are dealing with new partners, who have nothing to do with the segmented communities of the traditional society? Isn't the confrontation opposing new partners — i.e. the "modern" State—on the one hand, and the urbanised, pauperised, and politicised masses, on the other hand? In Senegal, there are two elites confronting each other today: the modernists (who support secularity, and want to own the western values), and the traditionalists (who are committed to the local cultural symbols). Each side wants to mobilise the masses around its vision and projects, without realising that it is substituting itself for the masses, while it fears to let them really express themselves. We should therefore confess that we are in the presence of three stakeholders, with three different voices and aspirations. What is striking in this process in Senegal, beyond the limits where radical Islam encloses its claim, is this curious re-discovery of Islam as the lieu of widening of the public space, the basis for the social values, and the basis of the solidarity and ethics as essential values needed for any community to be achievable and even thinkable (Bayart, 1993, pp. 299-310; Martin, 1999, pp. 75-84). In times of tensions and temptations of closing, it is to renew with the tradition, understood as a movement, an openness and a pluralism. The only power to oppose to the decaying forces, identifiable in a radical and nostalgic Islam, which advocates a spirit of compliance, is the open process (processus ouvert), the power of creating, changing, and innovating (Diagne, 2013, pp. 13-15). The requirement of becoming is carried by a human reason which understands the Quranic message as a living word and always in the present, which formulates new answers to new questions and conditions of modern life, by their continuous deepening. This pluralist Islam can defend ideas different from those of the Ancestors, without contradicting them. 


\section{References}

Appadurai, A. (1996). Modernity at large. Cultural dimensions of globalization. Minneapolis: University of Minnesota Press. Barry, B. (1988). La Sénégambie du XVème au XIXème siècle. Traite négrière, Islam et conquête coloniale. Paris: L’Harmattan. Bayart, J.-F. (1993). Religion et modernité politique en Afrique noire. Dieu pour tous et chacun pour soi. Paris: Karthala. Benga, N. (2010). Mise en scène de la culture et espace public au Sénégal. Africa Development, 35(4), 237-260.

Benoist, J. R. De. (2008). Histoire de l'Eglise catholique du Sénégal. Du milieu du XVe siècle à l'aube du troisième millénaire. Paris: Karthala.

Berque, J. (1993). Relire le Coran. Paris: Albin Michel.

Boilat, Abbé D. (1984). Esquisses Sénégalaises. Paris: Karthala, Paris, 1984, [first edition, Paris: P. Bertrand, 1853].

Brown, D. (1996). Rethinking tradition in modern Islamic thought. Cambridge: Cambridge University Press.

Coulon, C. (1981). Le Marabout et le Prince. Islam et pouvoir au Sénégal. Paris: Pédone.

Coulon, C. (1983). Les Musulmans et le pouvoir en Afrique noire. Religion et contre-culture. Paris: Karthala.

Diagne, S. B. (2001). Islam et société ouverte. La fidélité et le mouvement dans la pensée de Muhammad Iqbal. Dakar: Codesria. Paris: Maisonneuve et Larose.

Diagne, S. B. (2013). Comment philosopher en Islam?. Dakar: Jimsaan.

Diop, M.-C. (1981). La confrérie mouride : organisation politique et mode d'implantation urbaine. Paris: Université de Lyon II, Lyon [thèse de doctorat de 3ème cycle].

Diouf, L. (2001). Eglise locale et crise africaine. Le diocèse de Dakar. Paris: Karthala.

Diouf, M., \& Diop, M.-C. (1990). Le Sénégal sous Abdou Diouf. Etat et société. Paris: Karthala.

Diouf, M. (1997). Assimilation coloniale et identités religieuses de la civilité des Originaires des Quatre Communes du Sénégal. In C. Becker, S. Mbaye \& I. hioub (Eds.), AOF: réalités et héritages. Sociétés ouest-africaines et ordre colonial, 1895-1960 (pp. 837-850). Dakar: Direction des Archives du Sénégal.

Diop, M.-C. (1992). Sénégal. Trajectoires d'un Etat. Dakar: Codesria.

Diouf, M., \& Diop, M.-C. (1992). L’administration sénégalaise, les confréries religieuses et les paysanneries. Africa Development, $17(2), 65-87$

Diouf, M. (2001). Histoire du Sénégal. Le modèle islamo-wolof et ses périphéries. Paris: Maisonneuve et Larose.

Gellner, E. (1981). Muslim society. Cambridge: Cambridge University Press.

Gellner, E. (1982). Postmodernism, reason and religion. London: Routledge.

Gellner, E. (1994). Conditions of liberty. Civil society and its rivals. London: Penguin Books.

Gomez-Perez, M. (1994). L'islamisme à Dakar: d'un contrôle social total à une culture du pouvoir? Afrika Spectrum, 30(1), 79-98.

Hodgson, M. G. W. (1993). Rethinking world history. Essays on Europe, Islam and world history. Cambridge: Cambridge University Press.

Jenkins, R. (1996). Social identity. London: Routledge.

Kepel, G. (2003). La revanche de Dieu. Paris: Seuil.

Leimdorfer, F., \& Marie, A. (2003). L'Afrique des citadins. Sociétés civiles en chantier (Abidjan, Dakar). Paris: Karthala.

Lewis, B. (1998). Le langage politique de I'Islam. Paris: Gallimard.

Loimeier, R. (2000). L'islam ne se vend plus: The Islamic reform movement and the state in Senegal. Journal of Religion in Africa, 30, 185-187.

Magassouba, M. (1985). L’islam au Sénégal. Demain les mollahs? Paris: Karthala.

Mamdani, M. (2005). Good Muslim, bad Muslim. America, the Cold War and the roots of terror. Dakar: Codesria. NewYork: Pantheon Books.

Marshall, T. H. (1992). Citizenship and social class. London: Pluto.

Martin, J.-Y. (1999). Mondialité et identités. Reterritorialiser la citoyenneté. La Pensée, 319, 75-84.

Ndiaye, A. (2002). Une minorité confessionnelle dans l’Etat laïc. Point de vue d’un chrétien (pp. 601-616). Diop M. C. (Ed.), Le Sénégal contemporain. Paris: Karthala.

O’Brien, D. C. (1992). Le contrat social sénégalais à l'épreuve. Politique Africaine, 45, 9-20.

O’Brien, D. C., Diop, M.-C., \& Diouf, M. (2002). La construction de l’Etat au Sénégal. Paris: Karthala.

Otayek, R. (1993). Le radicalisme islamique au sud du Sahara. Da'wa, arabisation et critique de l'Occident. Paris: Karthala.

Otayek, R. (Ed.) (1999). Les identités contre la démocratie? Autrepart, 10, 11. 
Piga, A. (2002). Dakar et les ordres soufis. Processus socioculturels et développement urbain au Sénégal contemporain. Paris: L'Harmattan.

Robinson, D., \& Triaud, J.-L. (1997). Le temps des marabouts. Itinéraires et stratégies islamiques en Afrique Occidentale Française, vers 1880-1960. Paris: Karthala.

Rodinson, M. (1993). L'Islam: politique et croyance. Paris: Fayard.

Rosander, E. E., \& Westerlund, D. (1997). Africa Islam and Islam in Africa: Encounters between Sufis and Islamists. Athens: Ohio University Press.

Roy, O. (1992). L'échec de l'islam politique. Paris: Seuil.

Seck, A. (2007). Politique et religion. Contribution à une actualisation de la question. In A. Souley, X. Moyet, A. Seck \& Z. Maikoreima (Eds.), Islam, sociétés et politique en Afrique subsaharienne. Paris: Les Indes savantes.

Sèye, E. (2007). Mgr Hyacinthe Thiandoum. A force de foi. Paris: L’Harmattan.

Villalon, L. (2004). Islamism in West Africa: Senegal. African Studies Review, 47(2), 67.

Vuarin, R. (1990). L’enjeu de la misère pour l’Islam sénégalais. Revue Tiers-Monde, 30(123), 601-634.

Young, I. M. (1990). Justice and the politics of difference. Princeton: Princeton University Press. 